\title{
Organic Fertilization, Green Manure, and Vetch Mulch to Improve Organic Zucchini Yield and Quality
}

\author{
Francesco Montemurro ${ }^{1}$ and Angelo Fiore \\ Consiglio per la Ricerca e la sperimentazione in Agricoltura, Unità di ricerca \\ per lo studio dei sistemi colturali, (CRA-SSC), SS 106 Jonica, km 448.2, \\ 75010, Metaponto (MT), Italy
}

\section{Gabriele Campanelli}

Consiglio per la Ricerca e la sperimentazione in Agricoltura, Unità di ricerca per l'orticoltura (CRA-ORA), Via Salaria, 1-63030, Monsampolo del Tronto (AP), Italy

\section{Fabio Tittarelli \\ Consiglio per la Ricerca e la sperimentazione in Agricoltura, Centro per lo studio delle relazione tra pianta e suolo (CRA-RPS), Via della Navicella, 2-00184, Roma, Italy}

\section{Luigi Ledda}

Università degli Studi di Sassari, Dipartimento di Agraria, Viale Italia 39, 07100 Sassari, Italy

\section{Stefano Canali \\ Consiglio per la Ricerca e la sperimentazione in Agricoltura, Centro per lo studio delle relazione tra pianta e suolo (CRA-RPS), Via della Navicella, 2-00184, Roma, Italy}

Additional index words. Vicia sativa cover crop, green manure, roller crimper, anaerobic digestate, municipal solid waste compost, soil mineral nitrogen, organic farming, Cucurbita реро

Abstract. A 2-year field experiment was carried out in a Mediterranean environment to study the effects of vetch (Vicia sativa $L$.) residue management strategies incorporating green manure (GM) using a roller-crimper (RC) and different organic fertilizers (municipal solid waste compost, anaerobic digestate, and a commercial organic fertilizer) on organic zucchini (Cucurbita pepo L.) yield and quality. Zucchini yield was influenced positively by the vetch residue management strategy, although the response was significantly different between years. The vetch cover crop increased marketable zucchini yield in the first year by $\mathbf{4 6 . 6 \%}$ compared with the fallow (FA) treatment, indicating that this fertility-building crop could reduce off-farm nitrogen $(N)$ fertilizer input for subsequent crops. Averaging over 2 years of the experiment, marketable zucchini yield increased by $15.2 \%$ and $38 \%$ with the RC mulch and GM plow-down, respectively, compared with the FA treatment, although differences were significant in the first year only. The application of organic fertilizers in vetch management plots increased marketable zucchini yield by $\mathbf{2 1 . 8 \%}$ in the first year compared with the unfertilized control. This result is particularly relevant, because organic fertilizers were applied at $\approx 50 \%$ of the normal application rate for zucchini after taking into account biological $\mathbf{N}$ fixation attributable to the vetch. The concentrations of soil mineral $N$ at harvest were 19, 27, and $28 \mathrm{mg} \cdot \mathrm{kg}^{-1}$ for the RC, FA, and GM treatments, respectively. These mineral $\mathbf{N}$ concentrations indicated that a portion of applied organic fertilizer $\mathrm{N}$, and $\mathrm{N}$ attributable to vetch (GM and RC), remained in the soil at harvest, suggesting the potential for leaching, which should be taken into account in the overall fertilization program. These research findings suggest that effective vetch cover crop management and the application of organic fertilizers can improve yield and quality of organically managed zucchini.

Cover crops play an important role in organic farming and, in properly designed rotational systems, are able to provide fundamental ecological services to enhance agroecosystem sustainability (Blackshaw et al., 2005; Bugg and Waddington, 1994; Eyre et al., 2011; Uchino et al., 2011). Indeed, soil covered with plants is an effective way to suppress weed growth and reduce soil erosion and nutrient leaching while increasing soil organic matter and sustaining long-term soil fertility and crop production (Fageria et al., 2005). Legume cover crops are $\mathrm{N}$ sources and can reduce or replace off-farm $\mathrm{N}$ fertilizers (Perdigão et al., 2012; Smukler et al., 2012). In particular, the use of common vetch (Vicia sativa L.) as a cover crop may improve soil fertility and increase the yield of subsequent crops in the rotation. These positive effects may be the result of the roots and/or aboveground plant biomass, which contain a considerable amount of $\mathrm{N}$ and a relatively low carbon-to-nitrogen ratio $(\mathrm{C} / \mathrm{N})$ that results in a rapid release of plant-available $\mathrm{N}$ (BlancoCanqui et al., 2012; Gilmour et al., 1998).

To allow timely production of subsequent cash crops, the cropping cycle of cover crops in this type of rotational system is ended in advance of its physiological maturity by chemical and/or mechanical methods. In organic farming, cover crop termination is achieved by mechanical chopping and/or plowing, field disking, mowing, or crushing with a RC (Kornecki et al., 2009; Wortman et al., 2012).

Conservation tillage production systems using RC technology to end cover crops have been receiving increasing interest. The technique consists of one or two passages of the $\mathrm{RC}$ to flatten the cover crops, leaving a thick mulch layer into which the next crop is sown or transplanted (Teasdale et al., 2012). The mulch hinders the development of weeds during the critical growing period, contributes to reduced soil erosion, and increases soil moisture and fertility (Altieri et al., 2011; Luna et al., 2012; Teasdale and Mohler, 1993). The cover crop termination method influences the timing of the incorporation of the cover crop biomass carbon (C) inputs and the rate of $\mathrm{N}$ mineralization (Korsaeth et al., 2002). Although the RC technology has been widely used to end legume cover crops, some authors have reported system limitations as a result of differing cover crop/cash crop phenologies. Thus, difficulties have occurred when matching the cover crop growth stage that is most amenable to effective crop termination using the RC (Delate et al., 2012; Leavitt et al., 2011; Luna et al., 2012; Mischler et al., 2010; Teasdale et al., 2012). Consequently, the amount of $\mathrm{N}$ delivered to the cropping system by legume cover crops, and particularly by vetch, may not be sufficient nor adequately synchronized with the nutritional needs of the cash crop, affecting yield and economic performance (Delate et al., 2012). Thus, to reduce $\mathrm{N}$ deficiency, it may be necessary to supplement crop fertility with off-farm organiccompliant inputs to ensure acceptable crop yields.

Organic fertilizers and amendments can be derived from animal and vegetable origin processed in accordance with relevant organic certification rules. Two of the approved processes developed to transform organic materials into organic fertilizers are aerobic and anaerobic digestion. The aerobic transformation of organic wastes results in a stabilized, rich, humic-like substance generally characterized by slow mineralization rates in the soil. Anaerobic digestate is composed of organic substances in a chemically reduced form at low molecular weight, which, depending on the characteristics of the starting materials, can supply $\mathrm{N}$ and other nutrients at greater mineralization rates than compost (Montemurro 
et al., 2010a). Several studies have shown promising yield results from the application of compost, municipal solid waste (Montemurro et al., 2005a, 2007), and anaerobic digestates (Montemurro et al., 2010b) for different crop species.

Recent attempts have been made to assess the sustainability and crop performance of systems in which different cover crop management and organic fertilization strategies were combined (Mazzoncini et al., 2011; Rizk, 2012; Sainju et al., 2000; Vidal and López, 2005). However, most of the studies involved cereal crops and orchards with few on vegetable cropping systems (Canali et al., 2010; Delate et al., 2003; Montemurro et al., 2005b). This is true especially in the Mediterranean environment, where there is a substantial lack of knowledge regarding the combined effects of these approaches.

The objective of this research was to study the influence of different vetch residue management strategies in combination with the application of different organic fertilizers and amendments in an organic vegetable production system. Yield, yield components, crop quality, and soil nutritional status were determined in a two-season organic zucchini field experiment located in southern Italy.

\section{Materials and Methods}

Study site and weather conditions. The research was carried out during 2 years (200910 and 2010-11, indicated as 2010 and 2011, respectively) at Metaponto in southern Italy (lat. $40^{\circ} 24^{\prime} \mathrm{N}$; long. $16^{\circ} 48^{\prime} \mathrm{E}$; and $8 \mathrm{~m}$ above sea level) located on the experimental farm of the CRA-Research Unit for the Study of Cropping Systems.

The soil, classified as a Typic Epiaquert, contains low $\mathrm{N}\left(1.0 \mathrm{~g} \cdot \mathrm{kg}^{-1}\right)$ and organic matter $\left(19.0 \mathrm{~g} \cdot \mathrm{kg}^{-1}\right), 759 \mathrm{mg} \cdot \mathrm{kg}^{-1}$ of exchangeable potassium $(\mathrm{K}), 31.1 \mathrm{mg} \cdot \mathrm{kg}^{-1}$ of available phosphorus (P), and has a $\mathrm{pH}$ value of 8.4 with clay and silt contents of $60 \%$ and $36 \%$, respectively, and electrical conductivity of $0.48 \mathrm{mS} \cdot \mathrm{cm}^{-1}$ at 0 to $30 \mathrm{~cm}$ depth, increasing with depth. Cation exchange capacity is $27.1 \mathrm{meq}$ per $100 \mathrm{~g}$ of dry soil with a large amount of calcium and magnesium (15.5 and $8.6 \mathrm{mg} \cdot \mathrm{kg}^{-1}$, respectively). Soil water content, as a percentage of soil-dry weight, is $34.5 \%$ and $20.1 \%$ at field capacity $(-0.03 \mathrm{MPa})$ and permanent wilting point $(-1.5 \mathrm{MPa})$, respectively. The average bulk density is $1350 \mathrm{~kg} \cdot \mathrm{m}^{-3}$. The climate is classified as "accentuated

Received for publication 5 Feb. 2013. Accepted for publication 13 June 2013.

This research was supported by the Organic Farming Office of the Italian Ministry of Agriculture within the framework of the National Action Plan for Organic food and farming.

We thank Rosalba Scazzarriello, Angelo Raffaele Quaranta, Marco Favale, Corrado Ciaccia, Elena Testani, and Alberto Alianello for their contribution to field operations and soil and plant sampling and analysis.

${ }^{1}$ To whom reprint requests should be addressed; e-mail francesco.montemurro@entecra.it. thermomediterranean" according to the UNESCO-FAO classification (UNESCOFAO, 1963) with mean monthly temperatures of $8.8^{\circ} \mathrm{C}$ in the winter and $24.4^{\circ} \mathrm{C}$ in the summer. The site is characterized by winter temperatures, which can fall below $0{ }^{\circ} \mathrm{C}$, and summer temperatures, which can rise sometime above $40{ }^{\circ} \mathrm{C}$. Rainfall (average $490 \mathrm{~mm} /$ year) is unevenly distributed during the year and concentrated mainly in the winter months. The annual potential evaporation rate is high with a mean annual pan evaporation rate of $1549 \mathrm{~mm}$.

Before the experiment, a winter wheat crop was uniformly cultivated for 2 years without any fertilizer to establish a uniform soil nutrient level. As a consequence, there was not a substantial difference in soil nutrient levels among treatment plots at the beginning of the experiment. In 2010 we initiated the field experiment with a 2-year rotation of zucchini-cauliflower with the same experimental design and crop management. During the 2-year rotation, each plot received the same treatment to assess the residual effects of experimental and commercial organic fertilization.

Experimental design and crop management. The experiment design was a split plot with two factors and three replications. The main factor/plot was the vetch cover crop management and was compared with: 1) FA, in which vetch was not planted and the soil was tilled before zucchini planting; 2) GM, in which the vetch biomass was chopped and plowed; and 3) RC, in which the vetch biomass was flattened by a RC to create a mulch layer. Common vetch (cv. Buza) was sown at the rate of $80 \mathrm{~kg} \cdot \mathrm{ha}^{-1}$ in the GM and $\mathrm{RC}$ treatments on 20 Nov. 2009 and on 2 Dec. 2010 for experiment years 1 and 2, respectively. The vetch was ended at the first legume stage, when plants produced the first pods at the end of flowering. This stage occurred on 15 May 2010 and on 17 May 2011.

The RC system incorporated features of rolling/crimping with strip tillage by positioning coulters mounted on the front of the 2 - $m$-wide RC and chisels in line on the rear. The coulters and chisels cut a strip of 3 to

Table 1. Chemical characteristics of the commercial organic animal manure fertilizer (OAF), anaerobic digestate fertilizer, based on wine distillery waste (WDW), and composted municipal solid organic wastes $(\mathrm{MSW})$. $^{\mathrm{z}}$

\begin{tabular}{|c|c|c|c|c|}
\hline \multirow[b]{2}{*}{ Parameters } & & \multicolumn{3}{|c|}{ organic fertilizers } \\
\hline & & $\mathrm{OAF}$ & WDW & MSW \\
\hline Total nitrogen & $\mathrm{g} \cdot \mathrm{kg}^{-1}$ & 40.0 & $30.3 \pm 1.04$ & $26.2 \pm 1.67$ \\
\hline Available phosphorus & $\mathrm{g} \cdot \mathrm{kg}^{-1}$ & 4.0 & $1.17 \pm 0.08$ & $0.85 \pm 0.26$ \\
\hline Exchangeable potassium & $\mathrm{g} \cdot \mathrm{kg}^{-1}$ & 3.0 & $11.2 \pm 1.01$ & $1.20 \pm 0.31$ \\
\hline Total organic carbon & $\mathrm{g} \cdot \mathrm{kg}^{-1}$ & 410.1 & $192.0 \pm 4.95$ & $265.7 \pm 12.7$ \\
\hline Total extracted carbon & $\mathrm{g} \cdot \mathrm{kg}^{-1}$ & - & $118.8 \pm 7.21$ & $165.0 \pm 10.6$ \\
\hline Humic and fulvic acid & $\mathrm{g} \cdot \mathrm{kg}^{-1}$ & - & $90.1 \pm 2.12$ & $125.7 \pm 3.07$ \\
\hline Carbon-to-nitrogen ratio & & 10.25 & 6.33 & 10.14 \\
\hline $\mathrm{pH}$ & & 7.3 & $7.63 \pm 0.30$ & $8.62 \pm 0.37$ \\
\hline Moisture & $\%$ & 12.0 & $66.4 \pm 0.21$ & $47.92 \pm 0.56$ \\
\hline Copper & $\mathrm{mg} \cdot \mathrm{kg}^{-1}$ & - & $431 \pm 37.1$ & $125.1 \pm 11.6$ \\
\hline Zinc & $\mathrm{mg} \cdot \mathrm{kg}^{-1}$ & - & $65.9 \pm 4.8$ & $269.2 \pm 45.0$ \\
\hline Nickel & $\mathrm{mg} \cdot \mathrm{kg}^{-1}$ & - & $10.5 \pm 0.65$ & $6.15 \pm 2.0$ \\
\hline Lead & $\mathrm{mg} \cdot \mathrm{kg}^{-1}$ & - & $0.84 \pm 0.12$ & $33.8 \pm 10.5$ \\
\hline Cadmium & $\mathrm{mg} \cdot \mathrm{kg}^{-1}$ & - & $<0.05$ & $<0.05$ \\
\hline Chromium & $\mathrm{mg} \cdot \mathrm{kg}^{-1}$ & - & $3.03 \pm 0.07$ & $<0.05$ \\
\hline
\end{tabular}

${ }^{\mathrm{z}}$ Values are the mean of 2 years \pm SD.
$5 \mathrm{~cm}$ through the mulch to provide adequate space for transplant placement. This flattens the cover crop and creates a $20-$ to $30-\mathrm{cm}$ deep transplanting furrow, leaving a mulch layer in place, thus providing the expected agronomic and ecological benefits (i.e., weed control, soil protection). At the time of RC termination in both years, vetch in the GM treatment was plowed to a 15 - to $20-\mathrm{cm}$ depth like in the FA treatment where soil was tilled at the same depth to prepare for transplanting.

The second factor consisted of the following off-farm organic fertilizers and amendments within each vetch residue management system: 1) a commercial manure product consisting of organic animal fertilizer (OAF) (CRAI s.r.l., Rivoli Veronese, VR, Italy); 2) anaerobic digestate fertilizer, based on wine distillery waste (WDW); and 3) organic composted municipal solid wastes (MSW). These organic fertilizers were compared with an unfertilized control (N0) and their main characteristics and compositions are presented in Table 1. We used the two experimental organic fertilizers because the European Union (EU) allows their use in organic farming (Commission Regulation No. 889/2008 of 5 Sept. 2008 per EU Council Regulation No. 834/ 2007). The WDW was derived from distillation and extraction of tartaric acid from grape skins. The material was then processed under anaerobic conditions in a $6000-\mathrm{m}^{3}$ digester for 15 to $20 \mathrm{~d}$ with a mesophilic regime at 20 to $25^{\circ} \mathrm{C}$ neutralized to $\mathrm{pH} 7$ and maintained during the experimental period. After anaerobic digestion, flotation, and centrifugation processes, a stabilized and concentrated organic material was obtained. The compost was produced from municipal solid wastes in a closed and monitored processing plant. The composting process was based on mechanical separation of organic materials aimed at selecting the organic fraction suitable for composting. This fraction was ground with a hammer mill and sieved at $10 \mathrm{~mm}$. Finally, the material was composted in an open space and both the homogenization and oxygenation processes were ensured by means of continuous monitoring of humidity and temperature and by periodically turning the material. 
The organic materials (the same in both years) were applied as solid materials to the soil $\approx 20 \mathrm{~d}$ before transplanting zucchini at the rate of $100 \mathrm{~kg} \mathrm{~N} / \mathrm{ha}$. This rate was $\approx 50 \%$ lower than the recommended $\mathrm{N}$ fertilization rate for this crop in this specific environment and took into account the biological $\mathrm{N}$ fixation (BNF) contribution of the vetch. Zucchini was transplanted on 6 and 7 June 2010 and 2011, respectively, at $100 \mathrm{~cm} \times 70-\mathrm{cm}$ spacing resulting in a plant density of $\approx 1.4$ plants $/ \mathrm{m}^{2}$.

All treatments were irrigated with a specific volume of water determined by the rate of evapotranspiration (ETc) according to Doorenbos and Pruitt (1977) and crop coefficients applied according to Allen et al. (1998). The evaporation and meteorological data were recorded on an hourly basis by an automated data logger located close to the farm. Irrigation was applied when the ETc accumulated $24.3 \mathrm{~mm}$ from transplanting to first harvest and then $38.9 \mathrm{~mm}$ from first to last harvest. The irrigation water was calculated to reach $100 \%$ of available soil water for a soil depth of 0 to $40 \mathrm{~cm}$ at each irrigation. After this procedure, in both years, $\approx 2600 \mathrm{~m}^{3} \cdot \mathrm{ha}^{-1}$ of water was distributed over nine irrigation periods.

Data collection. Each year five random samples from each plot were taken to determine specific chemical characteristics of the WDW and MSW. Total C, humic and fulvic $\mathrm{C}$, total $\mathrm{N}$, total $\mathrm{P}$, and heavy metal content were determined using methods of Page et al. (1982). For the OAF we relied on the chemical content reported by the manufacturer. For each main plot of $20 \mathrm{~m}^{2}(5 \times 4 \mathrm{~m})$, total and marketable yields were determined twice weekly from a $6-\mathrm{m}^{2}$ (eight plants) area in the middle of each plot. Following local commercial standards, a representative $(\approx 30 \%)$ number of harvested zucchini was harvested by hand and weighed. In 2010, harvest dates were 5 July through 30 July with a cropping cycle of $55 \mathrm{~d}$. In 2011, harvest occurred from 6 July to 8 Aug. with a cropping cycle of $63 \mathrm{~d}$.

Soil mineral $\mathrm{N}$ (sum of $\mathrm{NO}_{3}{ }^{-}-\mathrm{N}$ and $\mathrm{NH}_{4}{ }^{+}-\mathrm{N}$ ) at a 0 - to $30-\mathrm{cm}$ depth was determined at $17,27,40$, and $52 \mathrm{~d}$ after transplanting (DAT) in 2010 and at 23, 35, 49, and 63 DAT in 2011. Soil mineral $\mathrm{N}$ was extracted by $2 \mathrm{M}$ $\mathrm{KCl}(1: 10 \mathrm{w} / \mathrm{v})$ and measured by a continuous flow colorimeter according to Krom (1980) and Henriksen and Selmer-Olsen (1970) for $\mathrm{NH}_{4}{ }^{+}-\mathrm{N}$ and $\mathrm{NO}_{3}{ }^{-}-\mathrm{N}$, respectively. Because the DAT differed between the 2 experimental years, we present data based on the phenological phases of zucchini [i.e., transplanting $(\mathrm{T})$, flowering $(\mathrm{F})$, start of harvest $(\mathrm{SH})$, and final harvest $(\mathrm{FH})]$. On the same DAT, at midlength on the most recently matured leaves from approximately five randomly selected plants from each plot, a Soil Plant Analysis Development (SPAD) reading was taken with a handheld chlorophyll meter (Minolta SPAD-502; Spectrum Technologies, Plainfield, IL). On the same leaves, zucchini petiole sap nitrate content was recorded with a Nitrachek reflectometer (Eijkelkamp, Giesbeek, The Netherlands). All laboratory measurements were carried out in triplicate.

Statistical analysis. Data were analyzed (SAS Institute, 1998) considering years as random factors and experimental treatments as fixed factors. Treatment effects were assessed through the General Linear Model procedure. Treatments means were compared using the protected least significant difference (LSD) and the Student-Newman-Keuls (SNK) tests for values from each sampling and mean treatment comparisons, respectively, at $P \leq 0.05$. The LSD and SNK differences for main effects and interactions were calculated using the appropriate standard error term. For most of the variables measured, the full analysis of variance, involving first-order variables and interactions, was significant for years and for the interactions (year $\times$ cover crop and year $\times$ organic fertilizer management); hence, the data are presented under these subcategories.

\section{Results}

Mean temperature was higher in the 200910 interannual year compared with 2010-11 (16.0 and $11.5{ }^{\circ} \mathrm{C}$, respectively; Fig. 1). In particular, in 2010-11, there was a lower mean temperature compared with the longterm historical record (1981-2008) of $15.2^{\circ} \mathrm{C}$. Total rainfall during 2009-10 was lower compared with 2010-11 (312 and $503 \mathrm{~mm}$, respectively) (Fig. 1) and when compared with the 1981-2008 average annual precipitation of $401 \mathrm{~mm}$. The WDW had higher values for total $\mathrm{N}$, available $\mathrm{P}$, and exchangeable $\mathrm{K}$ than MSW (Table 1). Conversely, the WDW contained reduced total organic $\mathrm{C}$, total extracted $\mathrm{C}$, humic and fulvic acids, and a lower $\mathrm{C} / \mathrm{N}$ ratio. The heavy metal fraction [i.e. copper $(\mathrm{Cu})$, zinc, nickel, lead, cadmium, and chromium] of the MSW compost, which was derived from the organic fraction of municipal solid wastes, was below the allowable limits, as stated in Italian law (Legislative decree No. 217, 2006). A similar heavy metal concentration was found in the WDW, with the exception of $\mathrm{Cu}$, which was $87 \%$ higher than acceptable thresholds, probably as a consequence of fungicide use in prior grape production.

Substantial differences in vetch biomass fresh weight were found between years both as GM and as RC mulch (Table 2). There was less variation between years in vetch dry matter. The greatest dry matter was obtained with GM vetch. The variability of climatic conditions between years may have affected total and marketable zucchini yields, but cover crop management and organic fertilizers also caused significant effects (Tables 3 and 4). Interactions between year $\times$ cover crop and year $x$ organic fertilizer management were

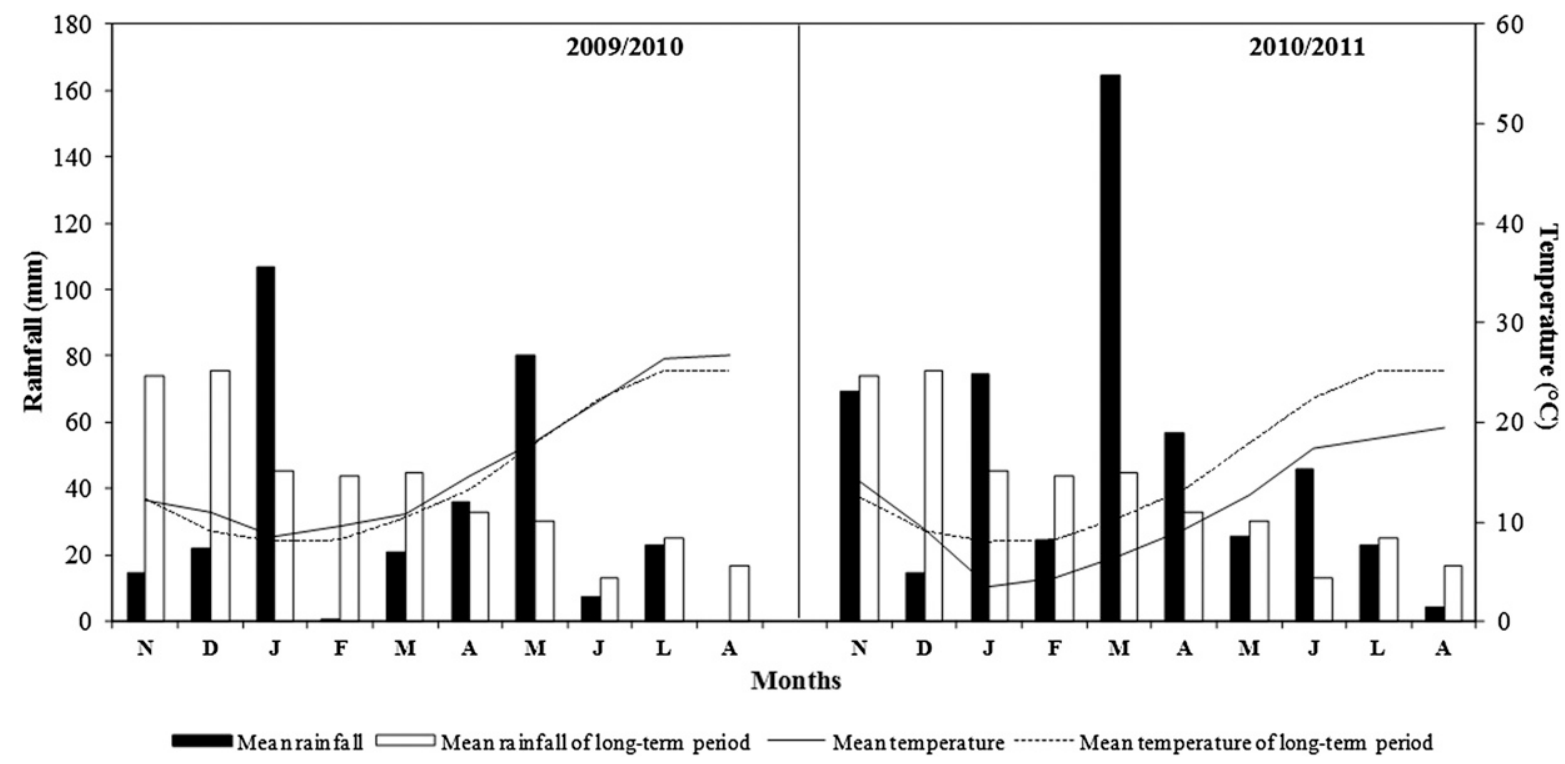

Fig. 1. Weather conditions (rainfall and mean temperatures) recorded during the zucchini growing seasons of 2009-10 and 2010-11. These values are compared with the rainfall and mean temperatures of 1981-2008. 
significant for total and marketable yield, whereas no significant interactions were determined for cover crop $\times$ organic fertilizer management or year $\times$ organic fertilizer management $\times$ cover crops. Among the other parameters evaluated, plant nitrate content responded similarly to cover crops and organic fertilizer management as total and marketable yields.

The 2-year average marketable yield in the GM and RC treatments was $26.6 \%$ greater than the FA treatment, but this increase was significant only in 2010 (46.6\%) (Table 4). Within each cover crop management system, there was a trend toward the GM treatment having the greatest total and marketable yields, but, again, differences were significant only in 2010. In 2010, the vetch cover crop increased marketable yield by $60.2 \%$ and $33.0 \%$ for $\mathrm{GM}$ and $\mathrm{RC}$, respectively, compared with FA. The RC treatment was associated with a $26.6 \%$ greater total yield than the FA treatment in 2010, although significant differences were found only between GM and FA. Average marketable yields in the WDW, OAF, and MSW treatments was $21.8 \%$ and $4.2 \%$ greater than the N0 treatment in 2010 and 2011, respectively.

In 2010, the greater marketable yield in the GM treatment was attributable to either a combination of a high number of marketable fruits with greater weight compared with the other treatments or attributable solely to the greater fruit weight (Table 4). In 2011, no difference was found for fruit weight among cover crop treatments. No significant difference was found for fruit weight among fertilization treatments in both years, but marketable fruit number was greater in the WDW and OAF compared with the MSW and N0 treatments in 2010. In 2011, no significant differences were found in total and marketable zucchini yields, fruit weight, and marketable fruit number among the organic fertilizer strategies.

Vetch residue management significantly influenced the SPAD readings in 2010 but not

Table 2. Vetch fresh and dry matter in 2010 and $2011 .^{\mathrm{z}}$

\begin{tabular}{lccccc}
\hline & \multicolumn{2}{c}{2010} & & \multicolumn{2}{c}{2011} \\
\cline { 2 - 3 } \cline { 5 - 6 } Treatment & Fresh matter $\left(\mathrm{t} \cdot \mathrm{ha}^{-1}\right)$ & Dry matter $\left(\mathrm{t} \cdot \mathrm{ha}^{-1}\right)$ & & Fresh matter (t.ha $\left.^{-1}\right)$ & Dry matter (t.ha $\left.{ }^{-1}\right)$ \\
\hline Cover crop & $36.6 \pm 0.56$ & $6.93 \pm 0.38$ & & $48.7 \pm 11.5$ & $6.03 \pm 1.42$ \\
GM & $27.6 \pm 3.7$ & $5.60 \pm 0.63$ & & $49.7 \pm 3.2$ & $6.16 \pm 0.40$ \\
RC & &
\end{tabular}

${ }^{\mathrm{z}}$ Values are the mean of three values for each year $\pm \mathrm{SD}$ and are presented by green manure (GM) and rollercrimper (RC) vetch cover crop management.

Table 3. Analysis of variance of total and marketable yields, fruit weight, marketable fruit number, SPAD readings, and nitrate content of zucchini. ${ }^{z}$

\begin{tabular}{|c|c|c|c|c|c|c|}
\hline Source & $\begin{array}{c}\text { Total yield } \\
\left(\mathrm{t} \cdot \mathrm{ha}^{-1}\right)\end{array}$ & $\begin{array}{c}\text { Marketable } \\
\text { yield } \\
\left(\mathrm{t} \cdot \mathrm{ha}^{-1}\right)\end{array}$ & $\begin{array}{c}\text { Fruit } \\
\text { wt } \\
(\mathrm{g})\end{array}$ & $\begin{array}{c}\text { Marketable } \\
\text { fruits } \\
\left(\mathrm{n} \cdot \mathrm{m}^{-2}\right)\end{array}$ & $\begin{array}{l}\text { SPAD } \\
\text { readings }\end{array}$ & $\begin{array}{c}\text { Nitrate } \\
\text { content } \\
\left(\mathrm{mg} \cdot \mathrm{kg}^{-1}\right)\end{array}$ \\
\hline$\overline{\text { Years (Y) }}$ & $* * *$ & $* * *$ & $*$ & $*$ & $*$ & $*$ \\
\hline Cover crop (CC) & $*$ & $* *$ & $*$ & $*$ & $*$ & $*$ \\
\hline $\mathrm{Y} \times \mathrm{CC}$ & $*$ & $*$ & NS & $*$ & NS & $*$ \\
\hline Fertilizer strategies $(\mathrm{F})$ & $* *$ & $* *$ & $*$ & $*$ & NS & $* *$ \\
\hline $\mathrm{Y} \times \mathrm{F}$ & $*$ & $*$ & * & NS & $*$ & $*$ \\
\hline $\mathrm{CC} \times \mathrm{F}$ & NS & NS & NS & NS & NS & NS \\
\hline $\mathrm{Y} \times \mathrm{CC} \times \mathrm{F}$ & NS & NS & NS & NS & NS & NS \\
\hline
\end{tabular}

${ }^{\mathrm{z}}$ The probability levels are presented by years, cover crop management, organic fertilizer strategies, and their interactions.

*, **, *** Significant at the $P<0.05,0.01$ and 0.001 , respectively. NS $=$ nonsignificant.

in 2011 (Table 5). In 2010, the GM and RC treatments increased the SPAD readings by $6.1 \%$ and $5.4 \%$, respectively, compared with the FA treatment, whereas no significant differences were found among fertilization treatments. Vetch residue management also significantly influenced the nitrate content in petiole sap in both years. The GM and the RC treatments increased nitrate content over the FA treatment by $94.1 \%$ and $60.7 \%$, respectively, in 2010 , and by $27.4 \%$ and $66.2 \%$, respectively, in 2011. Conversely, in 2011, no significant plant nitrate differences were observed between OAF and WDW treatments, but these were significantly greater than MSW with the N0 treatment showing intermediate values.

The mean soil mineral $\mathrm{N}$ concentration at harvest was 36 and $26 \mathrm{mg} \cdot \mathrm{kg}^{-1}$ in 2010 and 2011, respectively (Fig. 2). In 2010, the GM treatment had higher soil mineral $\mathrm{N}$ in the first two zucchini growth phases ( $\mathrm{T}$ and $\mathrm{F}$ ), but no treatment differences were observed by the end of the cropping cycle (Fig. 2A). In 2011, the GM treatment also had significantly higher mineral $\mathrm{N}$ compared with the FA and $\mathrm{RC}$ treatments over the entire cropping cycle (Fig. 2B). In 2010, there were significant differences in soil mineral $\mathrm{N}$ content overall growing phases among different fertilizer treatments (Fig. 3A-B). At the beginning of the cropping cycle, the MSW and WDW treatments had significantly lower mineral $\mathrm{N}$ compared with OAF and N0. The N0 treatment had the lowest mineral $\mathrm{N}$ at $\mathrm{F}$ and at $\mathrm{SH}$. No significant differences in mineral $\mathrm{N}$ were found between WDW and $\mathrm{OAF}$ at $\mathrm{SH}$ and $\mathrm{FH}$. In 2011, significant mineral $\mathrm{N}$ differences among treatments were found only in the second part of the zucchini cropping cycle ( $\mathrm{SH}$ and $\mathrm{FH}$ ), when absolute values were lower compared with 2010, and WDW and MSW values were greater than OAF.

\section{Discussion}

Effects of vetch residue management on zucchini yield and quality. In this experiment, the vetch cover crop increased $\mathrm{N}$ availability

Table 4. Zucchini total and marketable yields, fruit weight, and number of marketable fruits in 2010 and $2011 .^{\mathrm{z}}$

\begin{tabular}{|c|c|c|c|c|c|c|c|c|}
\hline \multirow[b]{2}{*}{ Treatment } & \multicolumn{2}{|c|}{2010} & \multicolumn{2}{|c|}{2011} & \multicolumn{2}{|c|}{2010} & \multicolumn{2}{|c|}{2011} \\
\hline & $\begin{array}{c}\text { Total } \\
\text { yield }\left(\mathrm{t} \cdot \mathrm{ha}^{-1}\right)\end{array}$ & $\begin{array}{c}\text { Marketable } \\
\text { yield }\left(\mathrm{t} \cdot \mathrm{ha}^{-1}\right)\end{array}$ & $\begin{array}{c}\text { Total yield } \\
\left(\mathrm{t} \cdot \mathrm{ha}^{-1}\right)\end{array}$ & $\begin{array}{c}\text { Marketable } \\
\text { yield }\left(\mathrm{t} \cdot \mathrm{ha}^{-1}\right)\end{array}$ & Fruit wt (g) & $\begin{array}{c}\text { Marketable } \\
\text { fruits }\left(n \cdot m^{-2}\right)\end{array}$ & Fruit wt (g) & $\begin{array}{l}\text { Marketable } \\
\text { fruits }\left(n \cdot m^{-2}\right)\end{array}$ \\
\hline \multicolumn{9}{|l|}{ Cover crop (CC) } \\
\hline GM & $17.5 \mathrm{a}^{\mathrm{y}}$ & $16.5 \mathrm{a}$ & 12.2 & 8.9 & $231.0 \mathrm{a}$ & $7.4 \mathrm{a}$ & 248.3 & $12.5 \mathrm{a}$ \\
\hline $\mathrm{RC}$ & $14.8 \mathrm{ab}$ & $13.7 \mathrm{ab}$ & 9.8 & 7.5 & $200.6 \mathrm{~b}$ & $6.6 \mathrm{a}$ & 224.9 & $9.2 \mathrm{~b}$ \\
\hline \multirow[t]{2}{*}{ FA (control) } & $11.6 \mathrm{~b}$ & $10.3 \mathrm{~b}$ & 10.6 & 8.1 & $187.4 \mathrm{~b}$ & $5.4 \mathrm{~b}$ & 228.9 & $10.8 \mathrm{~b}$ \\
\hline & $*$ & $* *$ & NS & NS & $*$ & $*$ & NS & $*$ \\
\hline \multicolumn{9}{|l|}{ Fertilizers (F) } \\
\hline WDW & $16.2 \mathrm{a}$ & $14.9 \mathrm{a}$ & 9.4 & 7.4 & 222.4 & $7.0 \mathrm{a}$ & 204.6 & 9.9 \\
\hline OAF & $17.7 \mathrm{a}$ & $16.7 \mathrm{a}$ & 12.9 & 9.6 & 226.2 & $7.4 \mathrm{a}$ & 242.0 & 11.5 \\
\hline MSW & $11.9 \mathrm{~b}$ & $10.8 \mathrm{~b}$ & 10.3 & 7.7 & 185.0 & $5.6 \mathrm{~b}$ & 232.7 & 10.9 \\
\hline \multirow[t]{2}{*}{ N0 (control) } & $12.7 \mathrm{~b}$ & $11.6 \mathrm{~b}$ & 10.8 & 7.9 & 191.7 & $5.8 \mathrm{~b}$ & 256.9 & 12.3 \\
\hline & $*$ & $*$ & NS & NS & NS & $*$ & NS & NS \\
\hline $\mathrm{CC} \times \mathrm{F}$ & NS & NS & NS & NS & NS & NS & NS & NS \\
\hline Means & 14.6 & 13.5 & 10.9 & 8.2 & 206.3 & 6.5 & 234.0 & 10.8 \\
\hline
\end{tabular}

${ }^{\mathrm{z}}$ Means are presented by cover crop management (CC) and organic fertilizer strategies (F). Within CC means are presented by green manure (GM), roller-crimper (RC), and fallow (FA), and within F by commercial organic animal manure fertilizer (OAF), anaerobic digestate fertilizer based on wine distillery waste (WDW), composted municipal solid organic wastes (MSW), and unfertilized control (N0).

${ }^{y}$ Within vetch cover crop management and fertilizers strategies, the values in each column followed by a different letter are significantly different according to Student-Newman-Keuls at $P \leq 0.05$. 
Table 5. SPAD readings and plant nitrate content in 2010 and $2011 .^{\mathrm{z}}$

\begin{tabular}{|c|c|c|c|c|}
\hline \multirow[b]{2}{*}{ Treatment } & \multicolumn{2}{|c|}{2010} & \multicolumn{2}{|c|}{2011} \\
\hline & SPAD & $\begin{array}{c}\text { Nitrate content } \\
\left(\mathrm{mg} \cdot \mathrm{kg}^{-1}\right)\end{array}$ & SPAD & $\begin{array}{l}\text { Nitrate content } \\
\left(\mathrm{mg} \cdot \mathrm{kg}^{-1}\right)\end{array}$ \\
\hline \multicolumn{5}{|l|}{ Cover crop (CC) } \\
\hline GM & $45.5 \mathrm{a}^{\mathrm{y}}$ & $1702 \mathrm{a}$ & 37.3 & $1131 \mathrm{a}$ \\
\hline $\mathrm{RC}$ & $45.2 \mathrm{a}$ & $1409 \mathrm{~b}$ & 38.3 & $1476 \mathrm{a}$ \\
\hline \multirow[t]{2}{*}{ Fallow (control) } & $42.9 \mathrm{~b}$ & $877 \mathrm{c}$ & 38.8 & 888 b \\
\hline & $* *$ & $*$ & NS & $*$ \\
\hline \multicolumn{5}{|l|}{ Fertilizers (F) } \\
\hline WDW & 44.7 & 1394 & 37.6 & $1393 \mathrm{a}$ \\
\hline OAF & 44.6 & 1242 & 38.1 & $1252 \mathrm{a}$ \\
\hline MSW & 44.4 & 1326 & 39.1 & 842 b \\
\hline \multirow[t]{2}{*}{ N0 (control) } & 44.3 & 1356 & 37.7 & $1173 \mathrm{ab}$ \\
\hline & NS & NS & NS & * \\
\hline $\mathrm{CC} \times \mathrm{F}$ & NS & $*$ & NS & * \\
\hline Means & 44.5 & 1329 & 38.1 & 1165 \\
\hline
\end{tabular}

${ }^{\mathrm{z}}$ Means are presented by cover crop management $(\mathrm{CC})$ and organic fertilizer strategies $(\mathrm{F})$. Within $\mathrm{CC}$ means are presented by green manure (GM), roller-crimper (RC), and fallow (FA), and within $\mathrm{F}$ by commercial organic fertilizer animal manure (OAF), anaerobic digestate fertilizer based on wine distillery waste (WDW), composted municipal solid organic wastes (MSW), and unfertilized control (N0).

${ }^{\mathrm{y}}$ Within vetch cover crop management and fertilizers strategies, the values in each column followed by a different letter are significantly different according to Student-Newman-Keuls at $P \leq 0.05$. for the following zucchini crop and resulted in increased yield in 1 of 2 years (2010), confirming the results of Hiltbrunner et al. (2007), Kuo and Jellum (2002), and Seo et al. (2006). The greatest yield response was obtained in the GM treatment, probably as a result of high aboveground biomass production that, when incorporated into soil, progressively mineralized and increased the available $\mathrm{N}$ content. The intermediate yields in the RC treatment could have been the result of a slower rate of mineralization of vetch biomass $\mathrm{N}$ after termination, whereas the remaining aboveground biomass did not completely mineralize during the zucchini cropping cycle. However, some of the $\mathrm{N}$ contained in the cover crop residues could be potentially available for the next crop. The GM and RC treatments were associated with an increase in marketable zucchini yield compared with the FA treatment in 2010, whereas no significant differences were found in 2011. In 2010, the greater total and
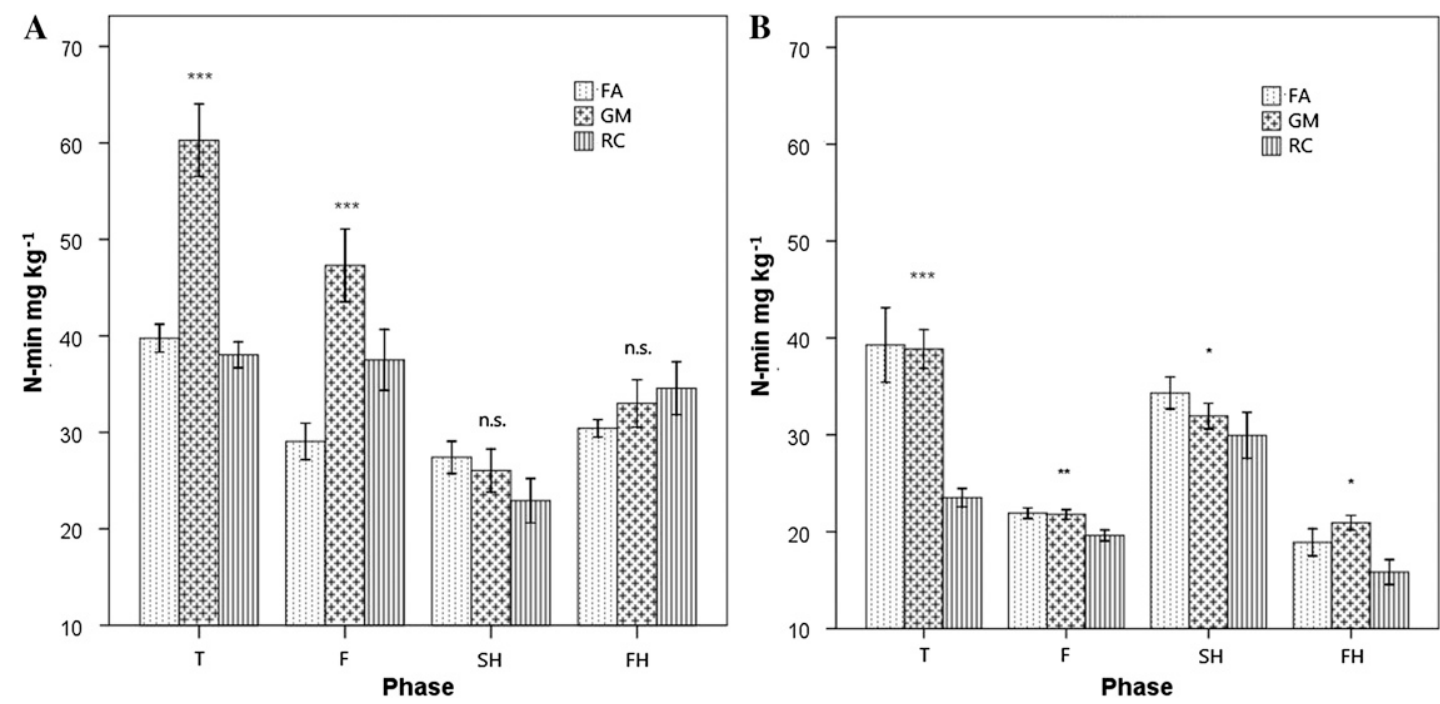

Fig. 2. Effects of vetch residue management on soil mineral nitrogen $(\mathrm{N})$ content in $2010(\mathbf{A})$ and $2011(\mathbf{B}) . *$, **, ***Significant at the $P \leq 0.05,0.01$, and 0.001 , respectively. $\mathrm{NS}=$ nonsignificant. The phenological phases of the vetch are: $\mathrm{T}=$ transplanting; $\mathrm{F}=$ flowering; $\mathrm{SH}=$ start of harvest; $\mathrm{FH}=$ final harvest.
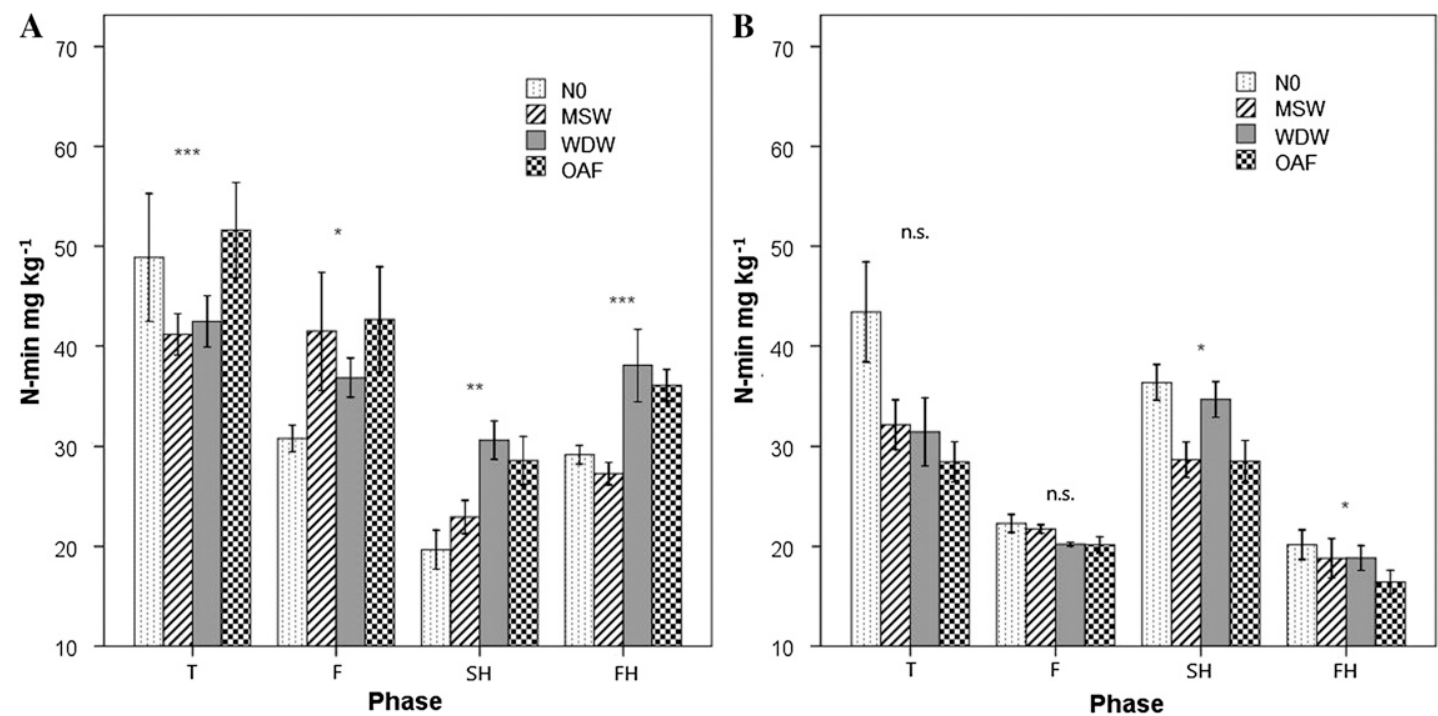

Fig. 3. Effects of fertilization strategies on soil mineral nitrogen $(\mathrm{N})$ content in $2010(\mathbf{A})$ and 2011 (B). *,**,***Significant at the $P \leq 0.05,0.01$, and 0.001 , respectively. $\mathrm{NS}=$ nonsignificant. The phenological phases of the vetch are: $\mathrm{T}=$ transplanting; $\mathrm{F}=$ flowering; $\mathrm{SH}=$ start of harvest; $\mathrm{FH}=$ final harvest. 
marketable yields in the GM treatment compared with the RC treatment was accompanied by a greater soil mineral $\mathrm{N}$ in the GM plots during the first zucchini growth phases. In their study, Cook et al. (2010) reported that vetch aboveground dry biomass ranged from 1.6 to more than $7.0 \mathrm{t} \cdot \mathrm{ha}^{-1}$, whereas in our experiment, the 2-year average biomass yield was $6.18 \mathrm{t} \cdot \mathrm{ha}^{-1}$. The same authors also found that vetch $\mathrm{N}$ concentration increased as vetch flowers approached anthesis, and when the vetch was ended, the total $\mathrm{N}$ amount in aboveground biomass was equivalent to standard inorganic fertilizer $\mathrm{N}$ application rates. Similarly, Ledgard (2001) and Tonitto et al. (2006) found that legumes can contribute up to $300 \mathrm{~kg} \mathrm{~N} / \mathrm{ha}$. Although much of this $\mathrm{N}$ comes from aboveground biomass, it has been reported that vetch root biomass may comprise as much as $12 \%$ of aboveground biomass amounts (Puget and Drinkwater, 2001; Sainju et al., 2005) and will decompose more slowly belowground. As such, $\mathrm{N}$ fertilization of zucchini after a cover crop should take into account BNF from vetch and posttermination mineralization rates. In a 2-year experiment involving rolled cover crops, Leavitt et al. (2011) found that marketable yields were reduced compared with the nocover crop control as a result of lower growing degree-days, thus delaying early vegetable growth resulting in reduced yields. Our experiment confirmed these results since 2011 , when zucchini production was postponed for 1 week (data not shown), yields were significantly lower than the first year. Finally, Wang et al. (2008a) found that an incorporated or mulched cover crop increased lettuce but decreased muskmelon, growth, and yield. Leavitt et al. (2011) also suggested that cover crop mulches were associated with lower levels of soil $\mathrm{N}$ (less than $10 \mathrm{mg} \mathrm{N} / \mathrm{kg}$ ) in the upper $15 \mathrm{~cm}$. In our experiment, the mean mineral $\mathrm{N}$ concentration at the same depth was substantially higher $(31 \mathrm{mg} \mathrm{N} / \mathrm{kg}$ ) in the GM and RC treatments, which were higher than the FA treatment. The higher soil mineral $\mathrm{N}$ content indicated that a portion of the $\mathrm{N}$ derived from the vetch was not used by the zucchini and remained in the soil. These residual $\mathrm{N}$ concentrations represent an important potential nutrient source in crop rotation and should drive the fertilization program for the succeeding crops. This is particularly true for vegetable production systems located in Mediterranean areas where crops are intensively cultivated year-round in tight sequences.

Effects of organic fertilization on zucchini yield and quality. An organic system based on organic-compliant fertilizers could reduce (Wang et al., 2008b) or increase (Delate et al., 2008) vegetable crop yield compared with conventional production. Indeed, Montemurro et al. $(2006,2007)$ found that soil quality may be ameliorated by using compost to increase soil organic matter. Additionally, Evanylo et al. (2008) found that compost $\mathrm{N}$ mineralization was not synchronous with the corn $\mathrm{N}$ assimilation and posed a leaching risk unless followed by a crop capable of using excess $\mathrm{N}$. In our study, in 2010, the application of organic fertilizers increased marketable zucchini yield by $21.8 \%$ compared with the N0. The greatest zucchini yields and quality were obtained in the WDW and OAF treatments. This result was probably attributable to the greater amount of available soil $\mathrm{N}$ where WDW and OAF were applied compared with the other treatments. Indeed, this is comparable to results obtained by Canali et al. (2011) and Montemurro et al. (2010b), who found that organic fertilizers and anaerobic digestates had greater mineralization rates in the soil when compared with compost. The higher levels of low-molecular-weight organic acids and a low $\mathrm{C} / \mathrm{N}$ ratio in the WDW material may help explain the greater $\mathrm{N}$ release rates observed in the WDW treatments. Furthermore, agricultural use of WDW must consider when the nutrients become plantavailable (Makadi et al., 2006). According to a rough estimation of the mineralization rate in soil, $\approx 60 \%$ to $80 \%$ of total organic $\mathrm{N}$ is released during a single cropping cycle, as reported by Montemurro et al. (2010b). Therefore, the incorporation of compost into soil must be done before crop transplanting, as was done here.

Current vegetable crop $\mathrm{N}$ fertilization recommendations are based on soil testing and crop nutritional requirements because none of the extractable soil $\mathrm{N}$ fractions is well correlated with growth or yield response. Gianquinto et al. (2006) and Westerveld et al. (2003, 2004) advocated estimating crop N requirements through the use of SPAD readings and plant nitrate meters. In our study, differences were not found for these variables between WDW and OAF probably as a result of a gradual release of nitrate from the organic substance contained in WDW, which did not reduce plant nitrate content and subsequent yield.

Soil application of WDW and MSW can benefit crop yields and increase soil fertility and has a lower risk of environmental pollution. Furthermore, because we found substantial differences in zucchini yield and quality among the fertilizer treatments, our findings confirm that the choice of the type of organic amendment or fertilizer is critical in organic vegetable production. However, as Montemurro et al. (2006) indicated, differences in soil properties such as organic matter and mineral nutrient content make it difficult to generalize.

Cover crop-organic fertilizers interactions. No interaction between cover crop and organic fertilizer management was found for zucchini yield and quality. Wang et al. (2008b) found that tomato yield and quality were improved by growing a cover crop [sunn hemp (Crotalaria juncea L.)] or by applying compost-based fertilizers, even if they did not observe any interaction between cover crops and organic fertilizers. Our results confirm these findings, because in 2010, the GM and RC mulch increased marketable zucchini yield by $60.2 \%$ and $33.0 \%$ compared with the FA, respectively. Conversely, in the same year, the application of WDW and OAF enhanced marketable zucchini yield by $28.4 \%$ and $44.0 \%$ compared with the N0, respectively. This result is particularly important if we take into account that organic fertilizers were broadcast at a $50 \%$ lower rate than typical $\mathrm{N}$ fertilization of zucchini with the balance provided by the contribution of vetch BNF. Furthermore, the RC termination of the vetch seemed to lead to better nitrate management, thus reducing the risk of leaching. However, no interaction between cover crop and organic fertilizer management was found, and, as a consequence, producers interested in using cover crops should choose those that will perform adequately in their particular region. In addition, organic producers should take into account that cover crop and fertilizing strategies are substantially influenced by rainfall and temperature. The findings of this research indicate that both cover crop and application of organic fertilizers and amendments in zucchini organic farming are constrained by environmental conditions and their effects are most valuable when a typical or favorable weather pattern occurs, as observed in 2010 .

In organically managed zucchini production, using alternative cover crop termination methods combined with the application of organic amendments of different mineralization rates could be an effective approach to modulate $\mathrm{N}$ availability to crops. However, very little research has been conducted that could lead to an understanding of the ecological underpinnings of these practices for each specific production environment. Further studies are need to evaluate long-term yield level and stability in systems using different cover crop termination strategies, especially in Mediterranean growing areas.

\section{Literature Cited}

Allen, R.G., L.A. Pereira, D. Raes, and M. Smith. 1998. Crop evapotranspiration-Guidelines for computing crop water requirements. FAO Irrigation and Drainage Paper No. 56. FAO, Rome, Italy.

Altieri, M.A., M.A. Lana, H.V. Bittencourt, A.S. Kieling, J.J. Comin, and P.E. Lovato. 2011. Enhancing crop productivity via weed suppression in organic no-till cropping systems in Santa Catarina, Brazil. J. Sustain. Agr. 35: 855-869.

Blackshaw, R.E., J.R. Moyer, and H.C. Huang. 2005. Beneficial effects of cover crops on soil health and crop management, p. 15-35. In: Pandalai, S.G. (ed.). Research Signpost, Trivandrum, India.

Blanco-Canqui, H., M.M. Claassen, and D.R. Presley. 2012. Summer cover crops fix nitrogen, increase crop yield, and improve soil-crop relationships. Agron. J. 104:137-147.

Bugg, R.L. and C. Waddington. 1994. Using cover crops to manage arthropod pests of orchards: A review. Agr. Ecosyst. Environ. 50:11-28.

Canali, S., C. Ciaccia, D. Antichi, P. Bàrberi, F. Montemurro, and F. Tittarelli. 2010. Interactions between green manure and amendment type and rate: Effects on organic potato and soil mineral $\mathrm{N}$ dynamic. J. Food Agr. Environ. 8:537-543.

Canali, S., E. Di Bartolomeo, F. Tittarelli, F. Montemurro, V. Verrastro, and D. Ferri. 2011. Comparison of different laboratory incubation procedures to evaluate nitrogen mineralization in soils amended with aerobic and anaerobic stabilized organic materials. J. Food Agr. Environ. 9:540-546. 
Cook, J.C., R.S. Gallagher, J.P. Kaye, J. Lynch, and B. Bradley. 2010. Optimizing vetch nitrogen production and corn nitrogen accumulation under no-till management. Agron. J. 102:1491-1499.

Delate, K., C. Cambardella, and A. McKern. 2008. Effects of organic fertilization and cover crops on an organic pepper system. HortTechnology $18: 215-226$

Delate, K., D. Cwach, and C. Chase. 2012. Organic no-tillage system effects on soybean, corn and irrigated tomato production and economic performance in Iowa, USA. Renew. Agr. Food Syst. 27:49-59.

Delate, K., H. Friedrich, and V. Lawson. 2003. Organic pepper production systems using compost and cover crops. Biol. Agr. Hort. 21:131-150.

Doorenbos, J. and W.O. Pruitt. 1977. Crop water requirements. FAO Irrigation and Drainage Paper No. 24 (revised). FAO, Rome, Italy.

Evanylo, G., C. Sherony, J. Spargo, D. Starner, M. Brosius, and K. Haering. 2008. Soil and water environmental effects of fertilizer-, manure-, and compost-based fertility practices in an organic vegetable cropping system. Agr. Ecosyst. Environ. 127:50-58.

Eyre, M.D., C.N.R. Critchley, C. Leifert, and S.J. Wilcockson. 2011. Crop sequence, crop protection and fertility management effects on weed cover in an organic/conventional farm management trial. Eur. J. Agron. 34:153-162.

Fageria, N.K., V.C. Baligar, and B.A. Bailey. 2005. Role of cover crops in improving soil and row crop productivity. Commun. Soil Sci. Plant Anal. 36:2733-2757.

Gianquinto, G., P. Sambo, and D. Borsato. 2006. Determination of SPAD threshold values for the optimisation of nitrogen supply in processing tomato. Acta Hort. 700:159-166.

Gilmour, J.T., A. Mauromoustakos, P.M. Gale, and R.J. Norman. 1998. Kinetics of crop residue decomposition: Variability among crops and years. Soil Sci. Soc. Amer. J. 62:750-755.

Henriksen, A. and A.R. Selmer-Olsen. 1970. Automatic methods for determining nitrate and nitrite in water and soil extracts. Analyst (Lond.) 95:514-518.

Hiltbrunner, J., M. Liedgens, L. Bloch, P. Stamp, and B. Streit. 2007. Legume cover crops as living mulches for winter wheat: Components of biomass and the control of weeds. Eur. J. Agron. 26:21-29.

Kornecki, T.S., A.J. Price, R.L. Raper, and F.J. Arriaga. 2009. New roller crimper concepts for mechanical termination of cover crops in conservation agriculture. Renew. Agr. Food Syst. 24:165-173.

Korsaeth, A., T.M. Henriksen, and L.R. Bakken. 2002. Temporal changes in mineralization and immobilization of $\mathrm{N}$ during degradation of plant material: Implications for the plant $\mathrm{N}$ supply and nitrogen losses. Soil Biol. Biochem. 34:789-801.

Krom, M.D. 1980. Spectrophotometric determination of ammonia: A study of a modified Berthelot reaction using salicylate and dichloroisocyanurate. Analyst (Lond.) 105:305-316.

Kuo, S. and E.J. Jellum. 2002. Influence of winter cover crop and residue management on soil nitrogen availability and corn. Agron. J. 94:501-508.

Leavitt, M.J., C.C. Sheaffer, D.L. Wyse, and D.L. Allan. 2011. Rolled winter rye and hairy vetch cover crops lower weed density but reduce vegetable yields in no-tillage organic production. HortScience 46:387-395.

Ledgard, S.F. 2001. Nitrogen cycling in low input legume-based agriculture, with emphasis on legume/grass pastures. Plant Soil 228:43-59.

Legislative decree No. 217. 2006. Suppl. Ord. G.U. number 38, 15 Feb.

Luna, J.M., J.P. Mitchell, and A. Shrestha. 2012. Conservation tillage for organic agriculture: Evolution toward hybrid systems in the western USA. Renew. Agr. Food Syst. 27:21-30.

Makadi, M., A. Tomocsik, V. Orosz, J. Lengyel, and A. Marton. 2006. Agricultural utilization of a liquid manure originated from a biogas plant, p. 635-641. In: Kraft, E., W. Bidlingmaier, M. De Bertoldi, L.F. Diaz, and J. Barth (eds.). Biological Waste Management, From Local to Global. Proceedings of ORBIT International Conference held during 13-15 September 2006 at Welmar, Germany.

Mazzoncini, M., T.B. Sapkota, P. Bàrberi, D. Antichi, and R. Risaliti. 2011. Long-term effect of tillage, nitrogen fertilization and cover crops on soil organic carbon and total nitrogen content. Soil Tillage Res. 114:165-174.

Mischler, R., S.W. Duiker, W.S. Curran, and D. Wilson. 2010. Hairy vetch management for no-till organic corn production. Agron. J. 102:355-362.

Montemurro, F., D. Ferri, F. Tittarelli, S. Canali, and C. Vitti. 2010a. Anaerobic digestate and on-farm compost application: Effects on lettuce (Lactuca sativa L.) crop production and soil properties. Compost Sci. Util. 18:184-193.

Montemurro, F., C. Vitti, M. Diacono, S. Canali, F. Tittarelli, and D. Ferri. 2010b. A three-year field anaerobic digestates application: Effects on fodder crops performance and soil properties. Fresen. Environ. Bull. 19:2087-2093.

Montemurro, F., M. Maiorana, G. Convertini, and D. Ferri. 2006. Compost organic amendments in fodder crops: Effects on yield, nitrogen utilization and soil characteristics. Compost Sci. Util. 14:114-123.

Montemurro, F., M. Maiorana, G. Convertini, and D. Ferri. 2007. Alternative sugar beet production using shallow tillage and municipal solid waste fertiliser. Agron. Sustain. Dev. 27:129-137.

Montemurro, F., M. Maiorana, G. Convertini, and F. Fornaro. 2005a. Improvement of soil properties end nitrogen utilisation of sunflower by amending municipal solid waste compost. Agron. Sustain. Dev. 25:369-375.

Montemurro, F., G. Convertini, D. Ferri, and M. Maiorana. 2005b. MSW compost application on tomato crops in Mediterranean conditions: Effects on agronomic performance and nitrogen utilization. Compost Sci. Util. 13:234-242.

Page, A.L., R.H. Miller, and D.R. Keeny. 1982. Methods of soil analysis, Part II. American Society of Agronomy, Madison, WI.

Perdigão, A., J. Coutinho, and N. Moreira. 2012. Cover crops as nitrogen source for organic farming in southwest Europe. Acta Hort. 933:355-361.

Puget, P. and L.E. Drinkwater. 2001. Short-term dynamics of root- and shoot derived carbon from a leguminous green manure. Soil Sci. Soc. Amer. J. 65:771-779.

Rizk, M.H. 2012. Effect of some legume cover crops and organic fertilizer on petiole nutrient content, productivity and fruit composition of
'Thompson seedless' grapevines. Acta Hort 933:381-387.

Sainju, U.M., B.P. Singh, and W.F. Whitehead. 2000. Cover crops and nitrogen fertilization effects on soil carbon and nitrogen and tomato yield. Can. J. Soil Sci. 80:523-532.

Sainju, U.M., W.F. Whitehead, and B.P. Singh. 2005. Biculture legume-cereal cover crops for enhanced biomass yield and carbon and nitrogen. Agron. J. 97:1403-1412.

SAS Institute. 1998. SAS/STAT user's guide, Version 6.12. Cary, NC.

Seo, J.H., J.J. Meisinger, and H.J. Lee. 2006. Recovery of nitrogen-15-labeled hairy vetch and fertilizer applied to corn. Agron. J. 98:245254.

Smukler, S.M., A.T. O'Geen, and L.E. Jackson. 2012. Assessment of best management practices for nutrient cycling: A case study on an organic farm in a Mediterranean-type climate. J. Soil Water Conserv. 67:16-31.

Teasdale, J.R., S.B. Mirsky, J.T. Spargo, M.A. Cavigelli, and J.E. Maul. 2012. Reduced-tillage organic corn production in a hairy vetch cover crop. Agron. J. 104:621-628.

Teasdale, J.R. and C.L. Mohler. 1993. Light transmittance, soil temperature, and soil moisture under residue of hairy vetch and rye. Agron. J. 85:673-680.

Tonitto, C., M.B. David, and L.E. Drinkwater. 2006. Replacing bare fallows with cover crops in fertilizer-intensive cropping systems: A meta-analysis of crop yield and nitrogen dynamics. Agr. Ecosyst. Environ. 112:58-72.

Uchino, H., K. Iwama, Y. Jitsuyama, K. Ichiyama, E. Sugiura, and T. Yudate. 2011. Stable characteristics of cover crops for weed suppression in organic farming systems. Plant Prod. Sci. $14: 75-85$.

UNESCO-FAO. 1963. Bioclimatic map of the Mediterranean zone. UNESCO, Place de Fontanay, Paris, FAO, Viale di Caracalla, Rome, NS162/ III, $22 \mathrm{~A}$.

Vidal, M. and A. López. 2005. Cover crops and organic amendments to prevent nitrate contamination under a wet climate. Agron. Sustain. Dev. 25:455-463.

Wang, G., M. Ngouajio, M.E. McGiffen, Jr., and C.M. Hutchinson. 2008a. Summer cover crop and in-season management system affect growth and yield of lettuce and cantaloupe. HortScience 43:1398-1403.

Wang, Q., W. Klassen, Y. Li, and M. Codallo. 2008b. Cover crops and organic mulch to improve tomato yields and soil fertility. Agron. J. 101:345-351.

Westerveld, S.M., A.W. McKeown, M.R. McDonald, and C. Scott-Dupree. 2003. Chlorophyll and nitrate meters as nitrogen monitoring tools for selected vegetables in southern Ontario. Acta Hort. 627:259-266.

Westerveld, S.M., A.W. McKeown, C. ScottDupree, and M.R. McDonald. 2004. Assessment of chlorophyll and nitrate meters as field tissue nitrogen tests for cabbage, onions, and carrots. HortTechnology 14:179-188.

Wortman, S.E., C.A. Francis, M.L. Bernards, R.A. Drijber, and J.L. Lindquist. 2012. Optimizing cover crop benefits with diverse mixtures and an alternative termination method. Agron. J. 104:1425-1435. 